\title{
Mitochondrial DNA-related dystonia
}

INSERM

\section{Source}

INSERM. (1999). Orphanet: an online rare disease and orphan drug data base.

Mitochondrial DNA-related dystonia. ORPHA:254851

Maternally-inherited mitochondrial dystonia is a rare neurological mitochondrial DNArelated disorder characterized clinically by progressive pediatric-onset dystonia with variable degrees of severity. 